\title{
PENYELESAIAN ANAK YANG BERKONFLIK DENGAN HUKUM DALAM KONTEKS SOSIAL MASYARAKAT (Penghindaran Labeling Terhadap Anak)
}

\author{
Achmad Ratomi \\ (Fakultas Hukum Universitas Lambung Mangkurat Banjarmasin) \\ ratomi79ach@gmail.com
}

\begin{abstract}
Abstrak
The fact that there are some data that indicate the involvement of children in criminal acts. Criminal acts of children in society have forced the child "in conflict with the law". The settlement of child problem conflicting with the law in the context of society can be done with out of court by the principles of togetherness and openness. This method is much more beneficial for children's development, both physically and psychologically when compared to the punishment. Formal law enforcement should be avoided as far as possible to children who commit a crimes as long as there is no guarantee for their benefit. Because of this article, the author tries to find a solution how it should be to resolve the issue of children in conflict with the law..
\end{abstract}

Kenyataan bahwa ada beberapa data yang menunjukkan keterlibatan anak-anak yang dalam tindak pidana kriminal. Tindak pidana anak di masyarakat telah memaksa diri anak "berkonflik dengan hukum". Penyelesaian persoalan anak yang berkonflik dengan hukum dalam konteks sosial masyarakat dapat dilakukan dengan upaya damai di luar pengadilan dengan prinsip kebersamaan dan keterbukaan. Penyelesaian cara ini jauh lebih menguntungkan bagi perkembangan anak baik secara fisik maupun secara psikologis jika dibandingkan dengan pemidanaan. Penegak hukum secara formal hendaknya sejauh mungkin dihindari terhadap anak yang melakukan tindak kriminal selama tidak ada jaminan kemaslahatan bagi mereka. Karena itu melalui artikel ini penulis mencoba untuk mencarikan solusi bagaimana seharusnya menyelesaikan persoalan anak yang berkonflik dengan hukum.

Kata Kunci: Anak, Tindak Pidana, Kriminal

Sebuah data yang dilansir oleh Komisi Nasional Perlindungan Anak menyatakan, bahwa pelaku kriminal dari kalangan remaja dan anak-anak meningkat pesat. Berdasarkan data yang ada, terhitung sejak Januari hingga Oktober 2009, meningkat 35\% dibandingkan tahun sebelumnya. Pelakunya rata-rata berusia 13 hingga 17 tahun. Data ini menyebutkan, mulai Januari hingga Oktober 2009 jumlah kasus kriminal yang dilakukan anak-anak dan remaja tercatat 1.150, sementara pada 2008 hanya 713 kasus. Ini berarti ada peningkatan 437 kasus. Adapun jenis kasus kejahatan itu antara lain pencurian, narkoba, pembunuhan dan pemerkosaan. ${ }^{1}$

Meski peningkatan kasus kriminal anak sangat tinggi, hingga kini pemerintah belum

\footnotetext{
${ }^{1}$ Www.kpai.go.id
} 
memiliki rumah pembinaan khusus bagi anakanak yang bermasalah. Sejauh ini, pemerintah hanya memasukkan anak yang berkonflik dengan hukum ke dalam sel-sel Rumah Tahanan (Rutan) atau Lembaga Pemasyarakatan (LP). Padahal, Rutan bahkan LP Anak sekalipun tidak mampu memenuhi hak-hak anak, khususnya hak kebebasan dan hak tumbuh-kembang anak. Hal ini pun masih harus ditambah dengan sebagian besar anak-anak yang ditahan harus berbaur dengan para tahanan dewasa.

Semestinya penangananhukum terhadapanak harus tetap memperhatikan beberapa hal, seperti aspek psikologis, mengedepankan sosialisasi hukum, pendampingan psikologis, pemisahan tempat penahanan hingga pendampingan pengacara. Beberapa hal tadi harus dilakukan karena penanganan tanpa diimbangi program terpadu terkait pendidikan, kesehatan, bimbingan psikologis, dan keterlibatan komunitas akan mendorong kecenderungan anak untuk mengulangi perbuatan yang melanggar hukum.

Menurut data Komisi Perlindungan Anak Indonesia (KPAI), Indonesia merupakan negara yang paling banyak memidanakan anak. Ada 6.000 anak yang dipidanakan sampai Juli 2009. Sementara, 3.800 anak di antaranya mendekam di lembaga pemasyarakatan (Lapas). Padahal di seluruh Indonesia hanya ada 16 Lembaga Pemasyarakatan Anak. ${ }^{2}$

Beberapa studi menunjukkan bahwa mereka mendapat perlakuan yang buruk bahkan kadang-kadang lebih buruk dari perlakuan terhadap orang dewasa pada suatu situasi yang sama. Perlakuan buruk ini tidak hanya terjadi di Rumah Tahanan (Rutan) atau Lembaga Pemasyarakatan (Lapas) namun tindak kekerasan terhadap mereka sering dialami sejak berada di kantor polisi yang berupa tamparan, tendangan, bahkan kadang-kadang pelecehan seksual. Penyidikan di kantor polisi ini sebenarnya dalam rangkapenyusunan Berita Acara Pemeriksaan (BAP). Namun, kekerasan sering menjadi bagian dari upaya untuk memperoleh pengakuan. Bentuk kekerasan lain berupa tindakan memaksa anak untuk

${ }^{2}$ Tim Komisi Perlindungan Anak Indonesia, 2009 membersihkan kantor polisi dan mobil patroli. Rutan atau Lapas memberikan pengaruh buruk terhadap anak-anak di samping hak mendapat pendidikan baginya terabaikan.

Hal serupa tidak hanya ada di negara berkembang seperti Indonesia tetapi juga dialami di negara maju. Kini dipikirkan berbagai upaya alternatif sejalan dengan prinsip yang tercantum dalam Konvensi Hak Anak (KHA), yaitu prinsip "The Best Interest of The Child" dan pidana sebagai "The Last Resort". ${ }^{3}$ Hakhak anak yang berkonflik dengan hukum diatur dalam Pasal 40 KHA yang berbunyi "Negara-negara peserta mengakui hak setiap anak yang disangka, dituduh, atau diakui telah melanggar undang-undang hukum pidana diperlakukan dengan cara yang sesuai dengan peningkatan martabat dan harga dirianak, memperkuat penghargaan anak pada hak-hak asasi manusia dan kebebasan dasar orang lain, dengan mempertimbangkan usia anak dan hasrat negara untuk meningkatkan reintegrasi anak dan peningkatan perannya yang konstruktif dalam masyarakat".

Sedangkan Pasal 37 ayat b KHA yang berbunyi "Tidak seorang anak pun akan dirampas kemerdekaannya secara tidak sah dan sewenang-wenang. Penangkapan, penahanan, atau penghukuman seorang anak harus sesuai dengan hukum, akan diterapkan sebagai upaya terakhir (last resort), dan untuk jangka waktu yang paling pendek". Dalam Pasal 37 ayat c KHA dinyatakan "Setiap anak yang dirampas kemerdekaannya akan diperlakukan secara manusiawi, dihormati martabat kemanusiaannya, dan dengan memperhatikan kebutuhan-kebutuhan anak seusianya".

Di Indonesia, hak-hak anak yang berkonflik dengan hukum diatur di dalam Undang-Undang Nomor 3 tahun 1997 tentang Pengadilan Anak. Undang-undang mengatur tentang pemeriksaan terhadap anak yang harus dilaksanakan dalam suasana kekeluargaan. Setiap anak berhak didampingi oleh penasihat hukum. Tempat

${ }^{3}$ Alit Kurniasari, Studi Penanganan Anak Berkonflik dengan Hukum, (Jakarta: Departemen Sosial RI, 2008), h. 1 
tahanan anak harus terpisah dari tahanan orang dewasa. Dalam Undang-undang juga disebutkan bahwa penahanan dilakukan setelah sungguhsungguh mempertimbangkan kepentingan anak dan atau kepentingan masyarakat. Hukuman yang diberikan tidak harus di penjara atau tahanan melainkan dapat berupa hukuman tindakan dengan mengembalikan anak ke orangtua atau wali.

Jadi, atas dasar perundang-undangan tersebut, upaya-upaya yang seharusnya dilakukan pada anak-anak yang berkonflik dengan hukum adalah upaya diversi dan keadilan restoratif (Restorative Justice). Diversi adalah pengalihan cara penanganan kasus-kasus anak yang diduga telah melakukan tindak pidana dari proses formal dengan atau tanpa syarat kepada suatu proses informal. Namun, sampai saat ini belum ada dasar hukum yang khusus untukdiversi sehingga polisi menggunakan aturan hukum diskresi untuk melaksanakan diversi. Keadilan restoratif adalah proses yang melibatkan semua pihak dalam memecahkan masalah secara bersama-sama dan menangani akibat suatu tindak pidana di masa yang akan datang. Hal ini perlu diperhatikan dalam menangani anak yang berkonflik dengan hukum agar tujuan keadilan restoratif tercapai. Upaya-upaya keadilan restoratif bertujuan menghindarkan anak dari penahanan dan pelabelananak sebagai penjahat, terulangnya pelanggaran tindak pidana, dan anak bertanggung jawab atas perbuatannya.

Sebagai perbandingan, di Amerika Serikat, pengadilan anak (juvenile court) didasarkan pada asas parent patriae, dimana penguasa harus bertindak apabila anak-anak membutuhkan pertolongan dan bagi anak yang melakukan kejahatan tidak dijatuhi hukuman pidana tetapi harus dilindungi dan diberikan bantuan sesuai kebutuhan si anak. ${ }^{4}$ Tentu saja, proses hukum seperti ini sangat jauh berbeda dengan realitas di Indonesia.

Kendati telah diberlakukan Undang-Undang Nomor 3 Tahun 1997 tentang Pengadilan Anak, namun nyatanya sistem peradilan anak yang terjadi di Indonesia masih sangat compang${ }^{4}$ Ibid., h. 1 camping. Betapapun dalam pertimbangan undang-undang tersebut diakui bahwa anak adalah bagian dari generasi muda sebagai salah satu sumber daya manusia yang merupakan potensi dan penerus cita-cita perjuangan bangsa, yang memiliki peranan strategis dan mempunyai ciri dan sifat khusus, memerlukan pembinaan dan perlindungan dalam rangka menjamin pertumbuhan dan perkembangan fisik, mental dan sosial secara utuh, serasi, selaras, dan seimbang, namun nyatanya banyak anak-anak di Indonesia yang mengalami kezaliman secara hukum.

Pasal 5Undang-Undang Nomor 3 Tahun 1997 dinyatakan, dalam hal anak belum mencapai umur 8 (delapan) tahun melakukan atau diduga melakukan tindak pidana, maka terhadap anak tersebut dapat dilakukan pemeriksaan oleh Penyidik. (2) apabila menurut hasil pemeriksaan, Penyidik berpendapat bahwa anak sebagaimana dimaksud dalam ayat (1) masih dapat dibina oleh orang tua, wali, atau orang tua asuhnya, Penyidik menyerahkan kembali anak tersebut kepada orang tua, wali, atau orang tua asuhnya. (3) apabila menurut hasil pemeriksaan, Penyidik berpendapat bahwa anak sebagaimana dimaksud dalam ayat (1) tidak dapat dibina lagi oleh orang tua, wali, atau orang tua asuhnya, Penyidik menyerahkan anak tersebut kepada Departemen Sosial setelah mendengar pertimbangan dari Pembimbing Kemasyarakatan.

Proses seperti dinyatakan UU di atas, nyatanya sering diabaikan. Ketika diperiksa di kantor Kepolisian, anak tidak didampingi petugas kemasyarakatan, Psikolog atau Penasehat Hukum. Ada anak-anak ditahan di tahanan kepolisian, ada hakim yang memerintahkan anak ditahan dan banyak lagi kejanggalankejanggalan atau bahkan pelanggaran hukum yang dialami anak-anak yang (disangka atau terbukti) melakukan tindak pidana.

Benar statement Save the Children International Alliance, bahwa kondisi sekarang jauh lebih buruk bagi anak-anak bahkan bila dibandingkan dari 100 tahun lalu. ${ }^{5}$ Benar juga bahwa Indonesia bukanlahnegara hukum dan tapi negara undang-

${ }^{5}$ www.ChildrenInternationalAlliance.com 
undang, karena menyangkut perlindungan dan kesejahteraan anak, di Indonesia tak kurang ada 97 peraturan yang memiliki kekuatan hukum. ${ }^{6}$ Akhirnya, bagi penguasa yang dianugrahi kekuasaan, kewenangan dan berbagai kebijaksanaan harus lebih berkomitmen untuk memperhatikan dan melindungi anak-anak, karena mereka juga kita anggap penerus darah kita, penerus generasi bangsa-negara.

Anak adalah seseorang yang belum berumur 18 (delapan belas) tahun termasuk anak yang masih dalam kandungan. ${ }^{7}$ Hukum Perdata bericara lain (21 tahun), hukum Islam punya ukuran akil baliq, sedangkan pada Pasal 4 Ayat (1) tentang Pengadilan Anak menyebutkan batas umur 18 untuk dapat diajukan ke Sidang Anak. Mengenai umur ini berbagai macam ukuran dapat digunakan, namun dalam pembahasan ini kita ikuti aturan dalam Undang-Undang Republik Indonesia Nomor 23 Tahun 2002 tentang Perlindungan Anak dan Undang-Undang Nomor 3 Tahun 1997 tentang Pengadilan Anak.

Anak-anak merupakan masa depan dari suatu bangsa yang harus dipersiapkan sebagai penerus eksistensi kehidupan bangsa itu, yang ke depan akan menghadapi perkembangan lingkungan yang makin kompleks, melalui proses pembelajaran dan pertumbuhan anak terutama menyangkut: (1) pematangan fisik, (2) pematangan kecerdasan (intelektual), (3) pematangan perasaan (emosional), (4) pematangan sosial dan (5) pematangan susila (moral). ${ }^{8}$

Selanjutnya Wagiyati Soetodjo membagi perkembangan anak kedalam 3 (tiga) kurun waktu ( fase ) yaitu : (1) Fase pertama yaitu Masa Anak Kecil dan masa perkembangan kemampuan mental, pengembangan fungsifungsi tubuh, perkembangan emosional, bahasa bayi dan arti bahasa bagi anak-anak, masa kritis (trozalter) pertama dan tumbuhnya seksualitas awal pada anak, pada usia $0 \mathrm{~s} / \mathrm{d} 7$ tahun, (2)

\footnotetext{
${ }^{6}$ www.kpai.go.id

${ }^{7}$ Pasal 1 huruf a Undang-Undang Republik Indonesia Nomor 23 Tahun 2002 tentang Perlindungan Anak

${ }^{8}$ Emeliana Krisnawati, Aspek Hukum Perlindungan Anak. (Bandung: CV Utomo, 2005), h. 16
}

Fase Kedua yaitu Masa Kanak-kanak, dari umur 7 s/d 14 tahun, yang dibagi kedalam 2 (dua) yaitu (a) Masa anak Sekolah Dasar umur 7 - 12 tahun adalah intelektual, memasuki masyarakat di luar perasaan, kemauan serta kemampuan anak. ${ }^{9}$

Dalam proses pembelajaran dan pertumbuhan ini tidak semua anak-anak berjalan mulus, tidak semuanya berhasil melaksanakan proses tersebut sebagaimana seharusnya, baik karena kondisi orang tuanya yang tidak memungkinkan atau situasi yang terganggu sehingga proses tidak berjalan lancar, berakibat terdapat anak yang menjadi korban dari kondisi / situasi tersebut baik sebagai korban situasi atau korban kejahatan atau menjadi pelaku kejahatan.

Dalam hal yang terakhir yang menjadi pokok bahasan kita kali ini kita pisahkan kedalam perbuatan kenakalan remaja/ juvenile delinquency yaitu perilaku menyimpang dari anak-anak / remaja yang tidak meresahkan masyarakat dan perilaku menyimpang yang telah meresahkan masyarakat. Dari pembedaan perilaku inilah yang akan menentukan tindakan penanganan yang akan kita sarankan untuk dilakukan. Namun untukitu semua perlu dilakukan upaya perlindungan terhadap proses pembelajaran dan pertumubuhan anak-anak dan generasi muda suatu bangsa.

Perlindungan anak adalah segala kegiatan untuk menjamin dan melindungi anak dan hakhaknya agar dapat hidup, tumbuh, berkembang, dan berpartisipasi secara optimal sesuai dengan harkat dan martabat kemanusiaan, serta mendapat perlindungan dari kekerasan dan diskriminasi. ${ }^{10}$ Dengan berpedoman pada ide perlindungan anak agar mampu hidup, tumbuh, berkembang dan berpartisipasi dalam kehidupan mereka sendiri dan bangsa pada umumnya maka hak anak tersebut harus dapat dijamin keberlangsungannya.

Perlindungan Khusus adalah perlindungan yang diberikan kepada anak dalam situasi ${ }^{9}$ Wagiati Soetodjo, Hukum Pidana Anak, (Bandung: Rafika Aditama,2006), h. 29

${ }^{10}$ Pasal 1 huruf $\mathrm{b}$ Undang-Undang Republik Indonesia Nomor 23 Tahun 2002 tentang Perlindungan Anak 
darurat, anak yang berhadapan dengan hukum, anak dari kelompok minoritas dan terisolasi, anak yang dieksploitasi secara ekonomii dan/ atau seksual, anak yang diperdagangkan, anak yang menjai korban penyalahgunaan narkotika, alkohol, psikotropika, dan zat adiktif lainnya (napza), anak korban penculikan, penjualan, perdagangan, anak korban nkekerasan baik fisik dan /atau mental, anak yang menyandang cacat, dan anak korban perlakuan salah dan penelantaran. ${ }^{11}$ Dengan demikian anak yang berhadapan dengan hukum harus mendapatkan perlindungan.

Selanjutnya Pasal 64 Undang-Undang Nomor 23 Tahun 2002 dinyatakan bahwa: (1) Perlindungan khusus bagi anak yang berhadapan dengan hukum (Pasal 59) meliputi anak yang berkonflik dengan hukum dan anak korban tindak pidana, merupakan kewajiban dan tanggung jawab pemerintah dan masyarakat; (2) Perlindungan khusus bagi anak yang berhadapan dengan hukum sebagaimana dimaksud dalam ayat (1) dilaksanakan melalui: (a) Perlakuan atas anak secara manusiawi sesuai dengan martabat dan hak-hak anak; (b) Penyediaan petugas pendamping khusus anak sejak dini; (c) Penyediaan sarana dan prasarana khusus; (d) Penjatuhan sanksi yang tepat untuk kepentingan yang terbaik bagi anak; (e) Pemantauan dan pencatatan terus menerus terhadap perkem bangan anak yang berhadapan dengan hukum; (f) Pemberian jaminan untuk memperthankan hubungan dengan orangtua atau keluarga; dan (g) Perlindungan dari pemberitaan identitas melalui media massa dan untuk menghindari labelisasi.

\section{Karakteristik Budaya Hukum}

Budaya hukum pertama kali diperkenalkan oleh Lawrence M. Friedman, seorang sosiolog hukum dari Universitas Stanfords, menyatakan bahwa sistem hukum terdiri atas tiga komponen, substansi hukum, struktur hukum, dan budaya hukum. Menurut Lawrence M. Friedman, budaya hukum mengacu pada sikap, nilai, dan opini dalam masyarakat dengan penekanan pada hukum, sistem hukum serta beberapa

${ }^{11}$ Ibid., Pasal 1 huruf p bagian hukum. Budaya hukum merupakan bagian dari budaya umum kebiasaan, opini, cara bekerja dan berpikir yang mengikat masyarakat untuk mendekat atau menjauh dari hukum dengan cara khusus. ${ }^{12}$ Dari ketiga komponen di atas, budaya hukum merupakan komponen yang paling penting. Muladi melihat budaya hukum sebagai sistem hukum yang abstrak (abstract system) yang merupakan the climate of social force which determines how law is used, advoided or abused. Lebih lanjut, Muladi menulis bahwa tanpa budaya hukum ini sistem hukum akan tidak berdaya, seperti ikan mati dalam keranjang, bukan sebagai ikan yang berenang di lau. Dengan demikian, budaya hukum harus merupakan bagian sentral dari pembangunan bidang hukum. ${ }^{13}$

Dengan memperhatikan kedua konsep tersebut di atas, dapat disimpulkan bahwa budaya hukum berimplikasi terhadapjalannya suatu proses hukum. Bahkan, dapat dikatakan budaya hukum akam mempengaruhi penolakan dan penerimaan masyarakat terhadap suatu peraturan hukum. Hal ini sangat penting diperhatikan, karena suatu peraturan hukum tanpa dukungan dari masyarakat, dapat berakibat tidak berwibawanya peraturan hukum tersebut. Dukungan ini hanya akan diperoleh apabila apa yang telah ditetapkan sebagai suatu peraturan hukum oleh pihak yang berkompeten, selaras dengan keyakinan hukum masyarakat.

Ditaatinya hukum menurut Bachsan Mustafa, ada tiga sebab, yaitu: (1) Karena anggotaanggota masyarakat itu sendiri menghendaki agar peraturan-peraturan hukum diberlakukan terhadap mereka, karena mereka menyadari akan fungsi hukum, yaitu mengayomi, melindungi hak-hak hukum mereka, dan dapat memaksakan orang yang mempunyai kewajiban hukum, untuk memenuhi kewajibannya atas tuntutan orang yang berhak; (2) Karena anggotaanggota masyarkat sangat berkepentingan

\footnotetext{
${ }^{12}$ Lawrence M. Friedman, Legal System: A Social Science Perspective, (New York: Russel Sage Foundation, 1975), h. 8

${ }^{13}$ Muladi, Hak Asasi Manusia, Politik dan Sistem Peradilan Pidana, (Semarang: Badan Penerbit Universitas Diponegoro, 1997), h. 88
} 
akan berlakukanya perturan-peraturan hukum tersebut. Yang dimaksud kepentingan di sini adalah kepentingan sebagai keinginan atau tuntutan yang manusia mencoba memenuhinya, baik secara perorangan, berkelompok, atau dalam himpunan, yang karenanya harus diperhatikan oleh pihak yang mengatur hubungan-hubungan antar manusia atau menertibkan kelakukan manusia; (3) Karena hukum itu sebagai pernyataan kehendak dari pemerintah untuk mewujudkan tujuan-tujuan negara seperti yang tercantum dalam Pembukaan UUD 1945, yaitu: (a) Melindungi segenap bangsa Indonesia; (b) Memajukan kesejahteraan umum; (c) Mencerdaskan kehidupan bangsa; dan (d) Ikut serta melaksanakan perdamaian dunia. ${ }^{14}$

Dalam masyarakat hukum yang sederhana, kehidupan masyarakat terikat ketat oleh solidaritas mekanis, persamaan kepentingan dan kesadaran, sehingga masyarakat lebih menyerupai suatu keluarga besar, maka hukum cenderung berbentuk tidak tertulis. Bentuk hukum dikenal sebagai budaya hukum tidak tertulis (un written law) dan terdapat pada masyarakat-masyarakat tradisional seperti pada masyarakat Anglo-Saxon, Britinia, dan masyarakat-masyarakat tradisional lainnya, seperti pada masyarakat Eskimo, Indian, dan masyarakat hukum adat di Indonesia. ${ }^{15}$

Budaya hukum ini, yang dipandang sebagai budaya masyarakat Anglo-Saxon, kemudian ditarnsformasikan ke dalam bentuk hukum kebiasaan (customary law) atau kebiasaan hukum (legal custom). Dalam perkembangannya, budaya hukum Anglo-Saxon berkembang menjadi tradisi common law, yang kemudian menjadi salah satu dari tradisi hukum besar dunia, sedangkan hukum kebiasaan tetapa ada dan berkembang dalam masyarakat-masyarakat sederhana. ${ }^{16}$ Dalam bentuknya sebagai kebiasaan, hukum dianggap tumbuh dan berkembang dalam masyarakat. Hukum dibentuk dan diberlakukanoleh dan di dalam suatu masyarakat.

${ }^{14}$ Bachsan Mustafa, Sistem Hukum Indonesia Terpadu, (Bandung: Citra Aditya Bakti, 2003), h. 210211

${ }^{15}$ Lili Rasjidi dan I.B. Wyasa Putra, Hukum Sebagai Suatu Sistem, (Bandung: Mandar Maju, 2003), h. 156157

${ }^{16}$ Ibid., h. 157
Karakter khas dari budaya hukum ini adalah, pertama, hukum tidak tertulis; kedua, senantiasa mempertimbangkan dan memperhatikan kondisi psikologis anggota masyarakat hukum setempat; ketiga, senantiasa mempertimbangkan perasaan hukum, rasa keadilan dan rasa butuh hukum masyarakat; keempat, dibentuk dan diberlakukan oleh masyarakat tempat hukum itu hendak diberlakukan; kelima, pembentukan itu lebih merupakan proses kebiasaan. ${ }^{17}$

Penyelesaian Anak Yang Berkonflik Dengan Hukum Dalam Konteks Sosial Masyarakat

Bila seorang anak dilaporkan melakukan pelanggaran pidana, yang perlu dilakukan adalah mengupayakan penelaahan yang baik oleh beberapa pihak dan profesi agar anak mendapatkan diversi. Bila diversi tidak memungkinkan sekurang-kurangnya dilakukan diskresi. Dalam persoalan anak yang berkonflik dengan hukum, harus diupayakan keadilan restoratif. Sedangkan dalam pencegahan pelanggaran pidana pada anak dan remaja hendaknya kita mengacu pada "Pedoman Riyadh", yaitu Pedoman PBB bagi Pencegahan Kenakalan Remaja. Dalam pedoman tersebut disebutkan bahwa pencegahan kenakalan remaja memerlukan upaya segenap masyarakat agar mereka dapat berkembang secara harmonis dalam menumbuhkan kepribadiannya sejak usia dini sampai masa remaja. Upaya pencegahan kenakalan remaja dapat dilakukan melalui pendidikan nilai-nilai dasar budaya dan sosial negaranya untuk mengembangkan kemanusiaan dan peradaban. ${ }^{18}$

Penanganan hukum terhadap anak harus tetap memperhatikan beberapa hal, seperti aspek psikologis, mengedepankan sosialisasi hukum, pendampingan psikologis, pemisahan tempat penahanan hingga pendampingan pengacara. Beberapa hal tadi harus dilakukan karena penanganan tanpa diimbangi program terpadu terkait pendidikan, kesehatan, bimbingan

${ }^{17}$ Ibid.

${ }^{18}$ Paulus Hadisuprapto, Peradilan Restoratif: Model Peradilan Anak Indonesia Masa Datang, (Pidato Pengukuhan Guru Besar Dalam Bidang Kriminologi Pada Fakultas Hukum Universitas Diponegoro, Semarang, 18 Februari 2006), h. 29 
psikologis, dan keterlibatan komunitas akan mendorong kecenderungan anak untuk mengulangi perbuatan yang melanggar hukum. Untuk menjalankan beberapa langkah di atas, pemerintah perlu melakukan koordinasi lintas dinas khususnya dinas pendidikan, dinas sosial, dan dinas kesehatan yang bekerja sama dengan aparat kepolisian. Di samping itu, harus juga melibatkan seluruh stakeholder terkait dan masyarakat.

Namun, segala hal yang dilakukan akan percuma apabila tidak secara terbuka untuk memahami anak dan hak-hak mereka. Maka, pemahaman yang terbuka didasari kasih sayang terhadap anak-anak dan hak-hak mereka akan memunculkan sikap, perlakuan dan kebijakan yang lebih komperehensif terhadap anak, termasuk di dalamnya anak-anak yang berkonflik dengan hukum. Bahkan kalau perlu harus menghindari labelisasi 'anak nakal' atau 'anak jahat', meskipun mereka telah melakukan suatu kesalahan. Hal ini dapat mendorong nilai-nilai positif pada diri anak dan bukan sebaliknya.

Anak yang melakukan kejahatan sebenarnya tidak harus dijatuhi pidana, sebagaimana dimaksud dalam Pasal 22 dan Pasal 24 UndangUndang Nomor 3 Tahun 1997 tentang Pengadilan Anak. Sebenarnya penjatuhan pidana yang dilakukan seorang hakim, sebagai perampasan kemerdekaan terhadap seorang anak, harus sebagai hal ultimum remedium, sebagai pilihan terakhir dan pilihan ini tentu saja harus melalui pertimbangan sangat matang dan melibatkan banyak pihak berkompeten dan itu juga harus diyakini bertujuan untuk memberikan atau dalam rangka kepentingan yang terbaik bagi anak tersebut. Dan tentu mahfum, penjara Indonesia hari ini sangat tidak layak dalam konteks kepentingan terbaik bagi anak, baik dilihat dari aspek infrastruktur dan fasilitasnya maupun petugasnya. Malah yang terjadi sekarang, penjara anak juga dijejali tahanan orang dewasa yang merupakan titipan karena penjara dewasa over kapasitas.

Perlakuan khusus bagi anak sangat diperlukan karena pada dasarnya proses hukum yang dilakukan tersebut tujuannya tidak hanya sebagai proses untuk membuktikan kesalahannya dan apa akibat dari kesalahannya tersebut, jika terbukti. Hal penting yang juga harus dicari pembuktiannya adalah mengapa si anak melakukan penyimpangan tersebut serta apa dan bagaimana upaya yang seharusnya dilakukan baik oleh Pemerintah, masyarakat dan keluarga dalam menanggulangi perilakunya itu.

Hal ini diperlukan dan seharusnya menjadi nafas dalam suatu proses peradilan anak, karena, apabila merujuk kepada keadaan mental dan fisiknya yang belum matang, maka situasi, keadaan atau pengaruh dari luar dirinya memiliki peranan lebih besar dibanding yang berasal dari dirinya yang sebenarnya, sehingga anak memang tidak pada tempatnya untuk dibebankan tanggungjawab atas apa yang dia lakukan.

Oleh karena itu dari aspek kebijakan kriminal (criminal policy) perbuatan menyimpang yang dilakukan anak tidak dapat dan seharusnya tidak disamakan dengan penyimpangan yang dilakukan orang dewasa. Penanganan perkara tindak pidana yang dilakukan anak dengan demikian bukan hanya sekedar proses pembuktian kesalahannya tapi harus dapat membuktikan tindakan-tindakan yang berdasarkan situasi dan kondisi objektif si anak, bukan atas dasar criminal mind yang datang dari dalam diri si anak. ${ }^{19}$

Peradilan bagi anak yang melakukan penyimpangan pada hakikatnya bukan untuk menghukum tapi bertujuan untuk memberikan kepentingan yang terbaik kepada anak (the best interests of the child), kepentingan terbaik anak adalah merupakan prinsip yang seharusnya melandasi dalam setiap kebijakan dan tindakan yang dilakukan oleh siapapun. Pasal 3 Konvensi Hak Anak menyebutkan, "Dalam semua tindakan yang menyangkut anak- anak, baik yang dilakukan lembaga-lembaga kesejahteraan sosial Pemerintah atau swasta, pengadilan, para penguasa pemerintahan atau badan legislatif, kepentingan terbaik harus menjadi pertimbangan utama."

${ }^{19}$ Muladi dan Barda Nawawi Arief, Bunga Rampai Hukum Pidana, (Bandung: Alumni, 2007), h. 124 
Daniel S.Lev, mengemukakan dua macam budaya hukum, yaitu nilai-nilai hukum acara dan nilai-nilia hukum materiel. Nilai-nilai hukum acara berhubungan dengan sarana pengaturan sosial dan penanganalah konflik. Nilai-nilai ini adalah dasar kultur dari sistem hukum, dan mereka sangat membantu dalam menentukan sistem pemberian tempat kepada lembaga-lembaga hukum, politik, religi dan lain-lain pada setiap saat dalam sejarah suatu masyarakat. Sedangkan nilai budaya hukum materiel terdiri atas asumsi-asumsi fundamental mengenai penyebaran dan penggunaan sumber-sumber di masyarakat, kebaikan dan keburukan sosial dan sebagainya. ${ }^{20}$

Dalam konteks sosial masyarakat, penyelesaian konflik lebih dilandasi oleh prinsip kebersamaan dan keterbukaan. Tidak heran apabila para pihak dituntut tampil sendiri menyelesaiakan konflik yang melibatkan dirinya. Pihak ketiga biasanya hanya tampil sebagai mediator di antara mereka. Penyelesaian konflik dapat berlangsung secara efektif dan tuntas.

Banyak perkara yang melibatkan masyarakat justeru tidak diajukan ke pengadilan karena dianggap bertele-tele dan tidak tuntas. Lagi pula, cara ini tidak mempersoalkan tentang menang-kalah (win lose solution), melainkan menghasilkan menang-menang (win-win solution). Hal ini merupakan salah satu refleksi dari budaya hukum masyarakat yang cenderung mencari keselarasan dengan melibatkan para pihak ketiga dalam proses pengambilan keputusan melalui jasa baik pihak ketiga.

Intervensi bagi pelaku tidak perlu melalui proses formal sehingga anak terhindar dari proses sistem peradilan. Bila anak terpaksa harus menjalani proses peradilan sebaiknya anak dijauhkan dari pengaruh dan implikasi negatif. Bentuk keadilan restoratif akan mendorong anak untuk bertanggung jawab atas perbuatannya. Selain itu anak mendapat kesempatan mengganti kesalahan dengan berbuat baik pada si korban dan memelihara hubungan dengan keluarga korban. Pada akhirnya

${ }^{20}$ A.A.G. Peters, Hukum dan Perkembangan Sosial, Buku Teks Sosiologi Hukum, (Jakarta: Pustaka Sinar Harapan, 1988), h. 193 anak diberi kesempatan untuk rekonsiliasi dan penyembuhan dalam masyarakat yang dirugikan oleh tindak pidananya.

Upaya keadilan restoratif sebenarnya sudah diawali sejak tahun 1970 di Ontario dan di beberapa negara lain. Evaluasi program tersebut memuaskan baik dalam hal partisipasi si korban, kerugian yang ditimbulkan, mengurangi ketakutan korban, dan akhirnya juga mengurangi perilaku kriminal oleh yang bersangkutan. ${ }^{21}$ Pelaksanaan upaya ini masih harus diperjuangkan di Indonesia.

Penyelesaian perkara anak yang berkonflik dengan hukum secara damai yang dilakukan oleh tersangka (keluarganyaa) dengan korban melalui mediasi aparat kepolisian memang masih menimbulkan kontroversi. Ada yang berpendapat bahwa hal tersebut tidak dibenarkan dengan alasan bahwa secara yuridis formal, tindakan aparat hukum yang tidak mengajukan perkara ke pengadilan secara tegas melanggar asas legalitas yang menghendaki setiap perkara pidana harus diajukan ke pengadilan. Demikian juga pendapat yang menyatakan bahwa fenomena penghentian perkara pidana dengan alasan perdamaian sangat bertentangan dengan asas oprtunitas. Karena yang berhak mengenyampingkan perkara hanyalah Jaksa Agung sebagaimana yang tercantum dalam Pasal 35 huruf c Undang-Undang Nomor 16 Tahun 2004 tentang Kejaksaan Republik Indonesia, yang berbunyi “Jaksa Agung dapat mengesampingkan perkara demi kepentingan umum".

Apabila ditinjau dari segi legalistic-positivistik, pendapat di atas adalah benar. Namun, demi memenuhi tuntutan rasa keadilan masyarakat, hendaknya pengertian kepentingan umum dalam asas oportunitas tidak hanya ditekankan pada aspek kepentingan negara semata, melainkan harus pula meliputi aspek-aspek kepentingan umum lainnya. Menurut van Bemmelen, kepentingan umum dalam kaitannya dengan kewenangan deponir tersebut mengandung tiga makna, yaitu: (1) Demi kepentingan Negara, yaitu apabila penuntutan dilakukan berakibat suatu pengumuman (openbaring)

${ }^{21}$ Paulus Hadisuprapto, Peradilan Restoratif , h. 26 
yang tidak dikehendaki dari rahasia negara. Artinya, apabila suatu penuntutan dilakukan akan berakibat kerugian besar terhadap negara (pemerintah); (2) Demi kepentingan masyarakat, yaitu penyampingan perkara demi kepentingan masyarakat terjadi apabila tidak dituntutnya suatu perbuatan pidana karena secara sosial tidak dapat dipertanggungjawabkan. Termasuk dalam kategori ini perubahan nilai/pandangan di dalam masyarakat terhadap pantas tidaknya suatu perbuatan dijatuhi pidana; (3) Demi kepentingan pribadi, yaitu penyampingan perkara demi kepentingan pribadi terjadi apabila suatu perkara dianggap bukan tindak pidana serius dan si pelaku telah membayar ganti kerugian. Dalam hal ini masyarakat tidak mempunyai kepentingan dengan melakukan penuntutan terhadap pelaku. Artinya, keuntungan yang diperoleh dari penuntutan tidak seimbang dengan kerugian yang timbul terhadap pelaku dan masyarakat. ${ }^{22}$

Dengan melihat dasar tersebut, ada pendapat bahwa penyelesaian tindak pidana secara damai dapat dibenarkan dengan alasan: (1) Perdamaian untuk menyelesaikan suatu perkara pidana, sejauh perkara tersebut belum diajukan ke pengadilan, merupakan suatu hal yang regular terjadi, oleh karenanya dapatlah hal ini disebut regularity; (2) Sikap tindak ajeg (regulatary) ini, merupakan pemantulan dari budaya hukum (legal culture) yang hidup dalam masyarakat; (3) Perdamaian di sini dapatlah diartikan sebagai suatu hubugan yangs serasi (harmonis) antara mereka yang berperkara, yang berorientasi pada keadilan dan kebenaran. ${ }^{23}$

Menurut Chairul Huda, dewasa ini sistem peradilan pidana diberbagai negara, telah diterima secara resmi pandangan bahwa peradilan pidana bukanlah satu-satunya cara menyelesaikan masalah kejahatan. Bahkan suatu penyimpangan (diversion) yang dilakukan oleh polisi dan penuntut umum terhadap kejahatan sering dianggap lebih baik. Lebih

${ }^{22}$ (Hendi Suhendi, Bunga Rampai Hukum Pidana dan Acara Pidana, (Jakarta: Ghalia Indonesia,1986), h. 156157

${ }^{23}$ Kamal Firdaus, Seraut Wajah Hukum, (Bandung : Alumni, 1980), h. 34 lanjut Chairul Huda mengatakan bahwa diversion tidak mementingkan dikeluarkannya putusan pengadilan (pidana). Diversion bukan berarti menghindarkan terdakwa dari penjatuhan pidana perampasan kemerdekaan, dengan mengupayakan penjatuhan hukuman alternatif. Namun lebih jauh lagi, diversion yang menghindarkan terdakwa dari proses peradilan pidana. Dalam teori diversion yang dilakukan oleh polisi disebut sebagai police coution. ${ }^{24}$ Andrew Sander menekankan bahwa sistem peradilan pidana bertujuan menghindari adanya stigma. Polisi memilih anak-anak yang melakukan tindak pidana untuk ditawarkan mengadkan perbaikan terhadap korban (minta maaf, ganti rugi). Jika disepakati, maka proses pidana tidak dilanjutkan. Kelemahan sistem ini cukup membahayakan, yaitu dapat membuat polisi sebagai penuntut umum, hakim dan sekaligus pelaksana putusan.

Dengan demikian, maka apabila penerapan diversion tidak dilaksanakan secara hati-hati, artinya hanya bertumpu pada kepentingan negara saja, maka akan terkesan bahwa penyampingan perkara seolah hanya ditujukan pada kasus-kasus tertentu yang berkaitan dengan kepentingan pemerintah saja. Kondisi ini dapat menimbulkan disparitas yang dapat mendesak asas fundamental dalam hukum acara pidana yaitu asas persamaan di muka hukum (equality before the law). Disinilah dituntut keberanian dan kepekaan dari aparat penegak hukum untuk melakukan penemuan hukum (rechtsvinding) guna memenuhi rasa keadilan masyarakat.

\section{Menghindarkan Anak Dari Labeling}

Penyelesaian anak yang berkonflik dengan hukum tidak selamanya membuat efek jera terhadap anak. Banyak perkara anak yang diselesaikan melalui pengadilan justeru membuat pertumbuhan dan perkembangan anak terganggu terutama secara psikologis, walaupun penyelesaiannya itu tiak berujung pada pemidanaan. Selama proses peradilan

${ }^{24}$ Chairul Huda, "Kedudukan Subsistem Kepolisian Dalam Sistem Peradilan Pidana," Jurnal Hukum, No. 12 Vol. 6, 1999, h. 142 
(sejak di kepolisian sampai di pengadilan) saja sudah terbentuk stigma jahat (label) yang dilekatkan oleh masyarakat terhadap anak yang berkonflik dengan hukum. Dewasa ini perkembangan pemberian label yang dikemukakan masyarakat semakin meningkat. Biasanya label yang dikemukakan masyarakat adalah label yang negatif dan sasarannya adalah individu yang dianggap menyimpang. Individu yang rentan terhadap label adalah anak, dimana pada masa anak adalah masa pencarian identitas dan pada masa ini anak harus bisa melewati krisisnya agar tidak terjadi kebingungan identitas.

Menurut Howard S. Becker, kajian terhadap teori label menekankan kepada dua aspek, yaitu: (1) Menjelaskan tentang mengapa dan bagaimana orang-orang tertentu diberi cap atau label; (2) Pengaruh/efek dari label sebagai suatu konsekuensi penyimpangan tingkah laku. ${ }^{25}$ Dengan demikian, reaksi masyarakat terhadap suatu perilaku dapat menimbulkan perilaku jahat. Kemudian F.M. Lemert, terkait dengan masalah kejahatan yang dilakukan, membedakan tiga bentuk penyimpangan, yaitu: (1) Individual deviation, dimana timbulnya penyimpangan diakibatkan tekanan psikis dari dalam; (2) Situational deviation, sebagai hasil stres atau tekanan dari keadaan; (3) Systematic deviation, sebagai pola-pola perilaku kejahatan terorganisir dalam sub-sub kultur atau sistem tingkah laku. ${ }^{26}$

Kemudian F.M. Lemert membedakan antara penyimpangan primer (primary deviance) dan penyimpangan sekunder (secondary deviance). Penyimpangan primer muncul dalam konteks sosial, budaya dan yang sangat bervariasi dan hanya mempunyai efek samping bagi struktur fisik individu. Pada dasarnya, penyimpangan primer tidak mengakibatkan reorganisasi simbolis pada tingkat sikap diri dan peran sosial. Penyimpangan sekunder adalah perilaku menyimpang atau peran sosial yang berdasar

${ }^{25}$ Lilik Mulyadi, Kajian Kritis Dan Analitis Terhadap Dimensi Teori-Teori Kriminologi Dalam Perspektif Ilmu Pengetahuan Hukum Pidana Modern, (Malang: Tanpa Penerbit,2009), h. 16

${ }^{26}$ K. Sunarto, Pengantar Sosiologi, (Jakarta: Lembaga Penerbit FEUI, 2004), h. 26 pada penyimpangan primer. Para ahli teori label mengemukakan bahwa penyimpangan sekunder adalah yang paling penting, karena merupakan proses interaksi antara orang yang dilabel dengan pelabel dan pendekatan ini sering disebut teori interaksi.

Lebih lanjut F.M. Lemert mengatakan, teori labeling adalah penyimpangan yang disebabkan oleh pemberian cap/ label dari masyarakat kepada seseorang yang kemudian cenderung akan melanjutkan penyimpangan tersebut. Lahirnya teori labeling, diinspirasi oleh perspektif interaksionisme simbolik dan telah berkembang sedemikian rupa dengan riset-riset dan pengujiannya dalam berbagai bidang seperti, kriminolog, kesehatan mental, kesehatan dan pendidikan. Teori labelling dipelopori oleh Lemert dan Interaksionisme simbolik dari Herbert Mead. Kemudian dikembangkan oleh Howard Becker pada tahun 1963. Labeling bisa juga disebut sebagai penjulukan/pemberian cap. Awalnya, menurut Teori Struktural devian atau penyimpangan dipahami sebagai perilaku yang ada dan merupakan karakter yang berlawanan dengan norma-norma sosial. Devian adalah bentuk dari perilaku. Howard Becker menyatakan bahwa label kriminal biasanya akan melekat pada orang yang pernah menjalani sidang peradilan. Walaupun mungkin pada akhirnya mereka diputuskan tidak bersalah. ${ }^{27}$

Labeling adalah sebuah definisi yang ketika diberikan pada seseorang akan menjadi identitas diri orang tersebut, dan menjelaskan orang dengan tipe bagaimanakah dia. Dengan memberikan label pada diri seseorang, kita cenderung melihat dia secara keseluruhan kepribadiannya, dan bukan pada perilakunya satu per satu.

Biddulph S. dan B. Steve dalam bukunya Raising a Happy Child banyak ahli yang setuju, bahwa bagaimana seseorang memandang dan merasakan dirinya sendiri akan menjadi dasar orang tersebut beradaptasi sepanjang hidupnya. Anak yang memandang dirinya baik akan mendekati orang lain dengan rasa percaya dan memandang dunia sebagai tempat

${ }^{27}$ Ibid., h. 28 
yang aman, dan kebutuhan-kebutuhannya akan terpenuhi. Sementara anak yang merasa dirinya tidak berharga, tidak dicintai akan cenderung memilih jalan yang mudah, tidak berani mengambil resiko dan tetap saja tidak berprestasi. Anak yang diberi label negatif dan mengiyakan label tersebut bagi dirinya, cenderung bertindak sesuai dengan label yang melekat padanya. Dengan ia bertindak sesuai labelnya, orang akan memperlakukan dia juga sesuai labelnya. Hal ini menjadi siklus melingkar yang berulang-ulang dan semakin saling menguatkan terus-menerus. ${ }^{28}$

Bagi anak-anak pengalaman mendapatkan label tertentu (terutama yang negatif) memicu pemikiran bahwa dirinya ditolak. Pemikiran bahwa dirinya ditolak dan kemudian dibarengi oleh sikap penolakan yang sesungguhnya, dapat menghancurkan kemampuan berinteraksi, mengurangi rasa harga diri, dan berpengaruh negatif terhadap kinerja seseorang dalam kehidupan sosial dan kehidupan kerjanya.

Bagi anak penting untuk merasa bahwa dirinya berharga dan dicintai. Perasaan ini ditemukan olehnya lewat respon orang-orang disekitarnya,. Kalau respon orang disekitarnya positif tentunya tidak perlu dicemaskan akibatnya. Tetapi, adakalanya orang disekitar si anak tersebut, tidak dapat menahan diri sehingga menunjukkan respon-respon negatif seputar anak tersebut. Walaupun sesungguhnya orang tersebut tidak bermaksud buruk dengan respon-responnya, namun tanpa disadari hal-hal yang dikatakan, sikap dan responnya, masuk dalam hati dan pikiran seorang anak dan berpengaruh dalam kehidupannya. Terutama dalam pembentukan identitas si anak tersebut.
Dengan demikian, maka para penegak hukum seharusnya mengambil tindakan dari sudut pandang empatis. Bukan melulu melihat mereka sebagai penjahat, melainkan sebagai korban. Korban ketidaktahuan akan definisi perilaku mereka, korban kondisi ekonomi yang memaksa mereka, bahkan korban dari kebijakan penguasa. Sejauh mingkin harus dihindari penyelesaian anak yang berkonflik dengan hukum melalui jalur pengadilan, karena seperti yang tersebut di atas, proses peradilan akan berpotensi membentuk kepribadian anak yang semakin mengarah kepada devian. Jika sudah demikian, maka tujuan dari sistem peradilan pidana yang berupa "mengusahakan agar mereka yang pernah melakukan kejahatan tidak mengulangi kejahatannya" tidak akan pernah tercapai.

\section{Penutup}

Penyelesaian anak yang berkonflik dengan hukum dalam konteks sosial masyarakat dapat dilakukan dengan cara penyelesaian diluar pengadilan dengan prinsip kebersamaan dan keterbukaan serta melibatkan semua pihak yang terkait seperti korban, pelaku dan pihak ketiga baik yang berasal dari tokoh masyarakat maupun dari lembaga penegak seperti kepolisian, dimana pihak ketiga tersebut bertindak sebagai mediator. Penyelesaian cara ini jauh lebih menguntungkan bagi perkembangan dan pertumbuhan anak baik secara fisik maupun secara psikologis. Dengan demikian, maka anak yang berkonflik dengan hukum akan terhindar dari cap/label/stigma negatif dari masyarakat sekitarnya. Karena bagaimanapun kehidupan bermasyarakat anak akan terjamin baik jika pandangan masyarakat terhadap anak tersebut baik pula. Penegak hukum sejauh mungkin menghindari jalur formal dalam proses penyelesaian anak yang berkonflik dengan hukum karena tidak ada jaminan penyelesaian melalui jalur formal akan tercapai tujuan-tujuan dari sistem peradilan pidana.

\footnotetext{
${ }^{28}$ Martina Rini S. Tamin, Label menyebabkan individu menjadi devian, http://www.e-psikologi.com
} 


\section{DAFTAR PUSTAKA}

Firdaus, Kamal. Seraut Wajah Hukum, Bandung : Alumni, 1980

Friedman, Lawrence M. Legal System: A Social Science Perspective, New York : Russel Sage Foundation, 1975

Hadisuprapto, Paulus. Peradilan Restoratif: Model Peradilan Anak Indonesia Masa Datang, Pidato Pengukuhan Guru Besar Dalam Bidang Kriminologi Pada Fakultas Hukum Universitas Diponegoro, Semarang, 18 Februari 2006

Huda, Chairul. “Kedudukan Subsistem Kepolisian Dalam Sistem Peradilan Pidana," Jurnal Hukum, No. 12 Vol. 6, 1999

Kurniasari, Alit. Studi Penanganan Anak Berkonflik dengan Hukum, Jakarta : Departemen Sosial RI, 2008

Krisnawati, Emeliana, Aspek Hukum Perlindungan Anak. Bandung : CV Utomo, 2005

Muladi, Hak Asasi Manusia, Politik dan Sistem Peradilan Pidana, Semarang: Badan Penerbit Universitas Diponegoro, 1997

--------, dan Barda Nawawi Arief, Bunga Rampai Hukum Pidana, Bandung : Alumni, 2007
Mulyadi, Lilik, Kajian Kritis Dan Analitis Terhadap Dimensi Teori-Teori Kriminologi Dalam PerspektifIlmu Pengetahuan Hukum Pidana Modern, Malang: Tanpa Penerbit, 2009

Mustafa, Bachsan. Sistem Hukum Indonesia Terpadu, Bandung: Citra Aditya Bakti, 2003

Peters, A.A.G. Hukum dan Perkembangan Sosial, Buku Teks Sosiologi Hukum, Buku II, Jakarta: Pustaka Sinar Harapan, 1988

Rasjidi, Lili dan I.B. Wyasa Putra, Hukum Sebagai Suatu Sistem, Bandung: Mandar Maju, 2003

Suhendi, Suhendi. Bunga Rampai Hukum Pidana dan Acara Pidana, Jakarta: Ghalia Indonesia, 1986

Sunarto, K, Pengantar Sosiologi, Jakarta: Lembaga Penerbit FEUI, 2004

Soetodjo, Wagiati. 2006. Hukum Pidana Anak. Bandung : Rafika Aditama

Tasmin, Martina Rini S, Label menyebabkan individu menjadi devian, http://www.epsikologi.com.

Tim KPAI, Indonesia Negara Terbanyak Memidanakan Anak, Kompas, Kamis 16 Juli 2009.

www.kpai.com. Penanganan Kasus Kriminal Anak 